\title{
PENGGUNAAN MEDIA PEMBELAJARAN I-SPRING PRESENTER UNTUK MENINGKATKAN MOTIVASI BELAJAR DAN HASIL BELAJAR PADA MATA KULIAH KEPERAWATAN DASAR NUTRISI
}

\author{
Rudy Alfiyansah ${ }^{1)}$ \\ ${ }^{11}$ Dosen Program Studi D3 Kebidanan STIKES Karsa Husada Kabupaten Garut. \\ Email: rudialfiyansah@yahoo.com
}

\begin{abstract}
The low learning motivation and learning outcomes in basic nursing courses in addition to the material presented allegedly less attractive, as well as lectures, is not supported by appropriate learning media. Through this research will study whether the use of a computer learning media presenter i-spring can increase learning motivation and learning outcomes of students. This research is expected to produce a concept of learning by utilizing i-spring media presenter. The study was conducted using a quantitative approach with quasiexperimental design methods to develop nonequivalent control group design. The instrument used in this study, questionnaires and tests. By using the Test Statistic $t$, a picture that media are learning the material on the nutritional needs of basic nursing courses using instructional media i-spring presenter, can significantly increase student motivation and learn outcomes. Based on these results was a recommendation to the faculty, it would be better if the learning media $\mathrm{i}$-spring presenter in completing the application program powerpoint. Those materials other lectures. Because the use of instructional media, the students not only enthusiastic (motivated) interact in lectures but shows the results of evaluation of the learning increased. Because the medium of learning many forms and types, in addition to the i-spring presenter, For next researchers can examine the factors factors that affect learning computer i-spring presenter and study the development of e-learning with one ispring program presenters included.
\end{abstract}

Keywords: I-Spring Presenter, Motivation, Learning Result

\section{A. PENDAHULUAN}

Proses pembelajaran dapat berjalan baik jika didukung oleh berbagai komponen pembelajaran yang berjalan sinergis untuk mencapai tujuan pembelajaran. Salah satu komponen pembelajaran yaitu media pembelajaran. Media pembelajaran adalah setiap orang, bahan, alat, atau peristiwa yang dapat menciptakan kondisi yang memungkinkan pebelajar menerima pengetahuan, ketrampilan dan sikap (Anitah, 2009).

Setiap institusi pendidikan mempunyai tujuan yang akan dicapai. Untuk mencapai tujuan tersebut, diperlukan seperangkat kelengkapan dalam berbagai bentuk dan jenisnya. Semua dapat diberdayakan menurut fungsi masingmasing kelengkapan. Kurikulum dapat dipakai oleh guru dalam merencanakan program pengajaran. Program institusi dapat dijadikan acuan untuk meningkatkan kualitas belajar mengajar. Sarana dan fasilitas yang tersedia harus dimanfaatkan sebaik-baiknya agar lebih memotivasi anak didik untuk belajar (Djamarah, 2002).

Media pembelajaran berbasis komputer, merupakan faktor eksternal dari hasil belajar yang dapat mempengaruhi motivasi belajar siswa. Menurut Nana Sudjana dan Ahmad Rivai (2001;137), menyatakan bahwa: "Kelebihan penggunaan komputer dalam pembelajaran diantaranya adalah Cara kerja baru dengan komputer akan membangkitkan motivasi kepada siswa dalam belajar". Dengan demikian, berdasarkan teori belajar kognitif dari Robert M Gagne, media pembelajaran berbasis komputer, dapat mempengaruhi motivasi belajar siswa.

Berdasarkan penelitian yang dilakukan oleh Rahmadi (2009), menunjukkan bahwa media pembelajaran komputer dapat meningkatkan motivasi belajar 119,4 dibandingkan dengan OHP 116,61 dan dapat meningkatkan prestasi 
23,50 dibandingkan dengan menggunakan OHP 18,50.

Bagaiamanakah aplikasi yang digunakan dalam program tersebut dalam memberikan kesuksesan dalam peningkatan prestasi belajar. Pada pelaksanaannya banyak sekali para pengajar baik guru maupun dosen yang melaksanakan pengajaran dengan media pembelajaran komputer dengan menggunakan aplikasi yang mudah dilakukan oleh guru maupun dosen tersebut. Aplikasi yang sering digunakan oleh guru maupun dosen dalam mengajar yaitu kebanyakan menggunakan program Microsoft power point.

Adapun beberapa keutamaan program aplikasi ispring presenter dalam menunjang gaya belajar mahasiswa dalam menyerap proses pembelajaran yaitu :

1. Ispring Presenter bekerja sebagai add-ins PowerPoint, untuk menjadikan file Power Point lebih menarik dan interaktif berbasis Flash dan dapat dibuka di hampir setiap komputer atau platform.

2. Ispring Presenter dikembangkan untuk mendukung e-learning juga dapat menyisipkan berbagai bentuk media, sehingga media pembelajaran yang dihasilkan akan lebih menarik, diantaranya adalah dapat merekam dan sinkronisasi video presenter, menambahkan Flash dan video YouTube, mengimpor atau merekam audio, menambahkan informasi pembuat presentasi dan logo perusahaan, serta membuat navigasi dan desain yang unik.

3. Mudah didistribusikan dalam format flash, yang dapat digunakan dimanapun dan dioptimalkan untuk web.

4. Membuat kuis dengan berbagai jenis pertanyaan/soal yaitu : True/False, Multiple Choice, Multiple response, Type In, Matching, Sequence, numeric, Fill in the Blank, Multiple Choice Text
Merujuk pada yang digambarkan tersebut menjadikan sebuah hipotesis bagaimanakah penggunaan komputer ispring presenter dalam meningkatkan motivasi belajar dan hasil belajar mahasiswa dalam menyerap proses pembelajaran supaya diharapkan mahasiswa maupun siswa dapat meningkatkan motivasi belajar maupun peningkatan hasil belajar.

\section{B. KAJIAN LETERATUR \\ 1. Pengertian dan Fungsi Media}

Gerlach \& Ely dalam Arsyad (2011:3), mengatakan bahwa "Media apabila dipahami secara garis besar adalah manusia, materi, atau kejadian yang membangun kondisi yang membuat siswa mampu memperoleh pengetahuan, keterampilan atau sikap". Gagne and Bringgs dalam Arsyad (2012:162) menyatakan bahwa "Media pembelajaran meliputi alat yang secara fisik digunakan untuk menyampaikan isi materi pengajaran, yang terdiri dari antara lain buku, tape recorder, kaset, video kamera, video recorder, film, slide, foto, gambar, grafik, televisi, dan komputer".

Gagne dalam Sadiman (2011:23), menjelaskan bahwa "Media dibagi atas tujuh macam kelompok yaitu benda untuk didemontrasikan, komunikasi lisan, media cetak, gambar diam, gambar gerak, film bersuara, dan mesin belajar". Pendapat ahli selanjutnya adalah Edling dalam Sadiman (2011:26). Menyatakan bahwa:

Media merupakan bagian dari enam unsur rangsangan belajar yaitu dua untuk pengalaman audio meliputi kodifikasi subjektif visual dan kodifikasi objektif audio, dua untuk pengalaman visual meliputi kodifikasi subjektif audio dan kodifikasi objektif visual, dan dua pengalaman belajar tiga dimensi meliputi pengalaman langsung dengan orang dan pengalaman langsung dengan benda benda.

\section{Motivasi Belajar}

Kegiatan pembelajaran di kelas, banyak timbul masalah berkenaan dengan masalah motivasi. Motivasi siswa menjadi 
rendah dikarenakan adanya berbagai macam faktor, salah satunya adalah faktor teman kelompok (teman sepergaulan), seperti teman sebangku. Maka tidak heran bila siswa ada yang termotivasi karena teman sebayanya, kadang siswa membuat suatu kelompok belajar untuk termotivasi antar sesama untuk ke arah yang lebih baik, Wentzel, Dalam Schunk (2012:241), menyatakan bahwa "Motivasi kelompok yang positif merupakan hal yang penting; penelitian menunujakan bahwa perilaku perilaku anak anak dan para remaja yang prososial dan bertanggung jawab memprediksi berbagai hasil prestasi”.

\section{Hasil Belajar}

Perubahan tingkah laku menurut Hamalik (2005:41) adalah "perubahan kepribadian pada diri seseorang". Tingkah laku mengandung pengertian yang luas meliputi segi jasmaniah (strukturil) dan segi rohaniah (fungsionil) yang kedua - duanya saling bertalian dan saling berinteraksi satu sama lain. Pola tingkah laku ini terdiri dari aspek yang meliputi pengetahuan, pengertian, sikap, keterampilan, kebiasaan, emosi, budi pekerti, apresiasi, jasmani, hubungan sosial, dan lain - lain.

Menurut sudjana (dalam Nur, 2010 : 4) mengemukakan bahwa "hasil yang diperoleh setelah mempelajari materi yang diwujudkan melalui perubahan pada diri siswa tersebut meliputi perubahan reaksi dan sikap siswa secara fisik maupun mental". Secara luas dapat dikatakan bahwa hasil belajar adalah hasil yang diperoleh siswa setelah melakukan kegiatan belajar yang dapat diukur dengan alat ukur tertentu.

Hasil belajar dipengaruhi oleh beberapa faktor seperti kecerdasan, motivasi, prestasi, kemampuan kognitif, yang kesemuanya termasuk faktor dari dalam diri siswa sedangkan faktor dari luar diri siswa seperti lingkungan dan instrumen guru dalam pembelajaran.

\section{Nutrisi dalam Ilmu Kesehatan}

Nutrisi adalah proses pengambilan zat-zat makanan penting dimana jumlah dari seluruh interaksi organisme dan makanan yang dikonsumsinya. Dengan kata lain nutrisi adalah apa yang manusia makan dan menggunakannya. (Ilmu Keperawatan Dasar : 2014). Adapun pengertian mengenai nutrien adalah zat kimia organik dan anorganik yang ditemukan dalam makanan dan diperoleh untuk penggunaan fungsi tubuh. Manusia memperoleh makanan atau nutrien untuk pertumbuhan dan pertahanan dari seluruh jaringan tubuh dan menormalkan fungsi dari semua proses tubuh.

\section{METODE PENELITIAN}

Metode penelitian ini menggunakan Quasi Eksperimental Design, teknik pengumpulan data dengan cara kuesioner, pre test dan post test untuk kelas kontrol dan kelas intervensi dengan menggunakan butir soal pilihan ganda. Adapun rumus uji validitas dengan teknik korelasi product moment dari karl pearson dan uji reliabitas menggunakan koefisien alfa dari cronbach. Untuk tabulasi data menggunakan 4 tahapan yaitu : tahap pengumpulan data, tahap editing, tahap koding, dan tahap tabulasi data. Peneliti juga melaksanakan uji kolmogorov smirnov test untuk melaksanakan uji normalitas, uji linearitas dan homogenitas sebelum melangkah pada analisis uji $\mathrm{t}$ (wilcoxon).

\section{HASIL DAN PEMBAHASAN}

Tabel 4.1

Deskripsi Motivasi Belajar Mahasiswa pada Kelompok Kontrol dan Eksperimen

\begin{tabular}{|c|c|c|c|}
\hline \multicolumn{2}{|c|}{ Kelompok } & \multicolumn{2}{|c|}{ Motivasi } \\
\hline & & Pretest & Posttest \\
\hline \multirow[t]{5}{*}{ Eksperimen } & Rata-rata & 121,13 & 131,16 \\
\hline & $\mathrm{N}$ & 31 & 31 \\
\hline & $\begin{array}{l}\text { Simpangan } \\
\text { Baku }\end{array}$ & 4,99 & 13,84 \\
\hline & Minimum & 115 & 115 \\
\hline & Maksimum & 131 & 158 \\
\hline
\end{tabular}




\begin{tabular}{|l|l|c|c|}
\hline Kontrol & Rata-rata & 119,20 & 124,333 \\
\cline { 2 - 4 } & $\mathrm{N}$ & 30 & 30 \\
\cline { 2 - 4 } & $\begin{array}{l}\text { Simpangan } \\
\text { Baku }\end{array}$ & 5,35 & 8,15 \\
\cline { 2 - 4 } & Minimum & 113 & 113 \\
\cline { 2 - 4 } & Maksimum & 130 & 137 \\
\hline
\end{tabular}

Motivasi pada kelompok eksperimen dan kontrol penilaiannya dibagi menjadi 3 bagian, yaitu :

a. Hasil skor $40-80$ mahasiswa dikategorikan kurang mempunyai motivasi dalam belajar

b. Hasil skor $81-120$ mahasiswa dikategorikan cukup mempunyai motivasi dalam belajar.

c. Hasil skor $121-160$ mahasiswa dikategorikan mempunyai motivasi yang baik dalam proses belajar mengajar.

Tabel 4.2

Deskripsi Hasil Belajar Mahasiswa pada Kelompok Kontrol dan Eksperimen

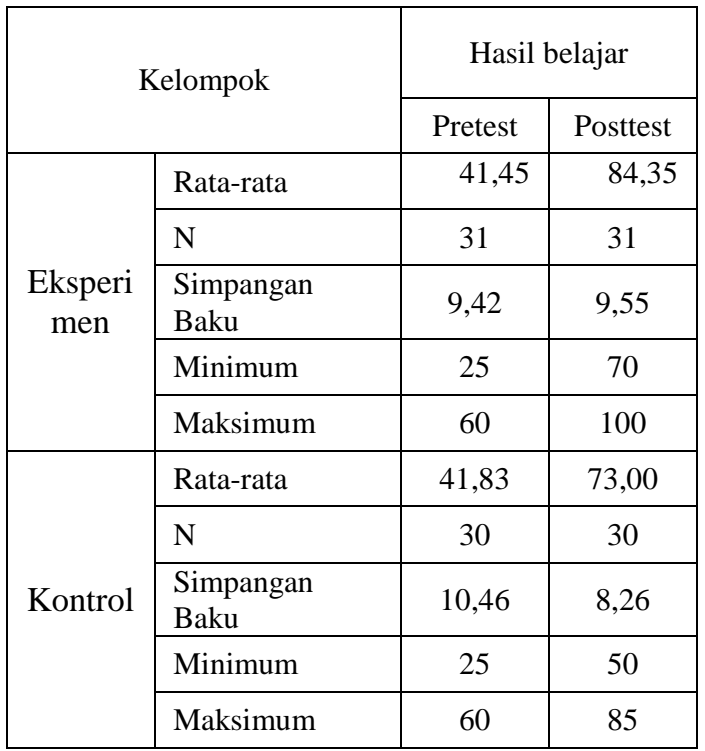

Hasil belajar pada kelompok eksperimen dan kontrol penilaiannya dibagi menjadi 3 bagian, yaitu :

a. Baik : apabila mahasiswa mendapatkan nilai 76 - 100 .

b. Cukup : apabila mahasiswa mendapatkan nilai $56-75$. c. Kurang : apabila mahasiswa mendapatkan nilai $40-55$.

Pengaruh Penggunaan Media Pembelajaran Komputer I-Spring Presenter Untuk Meningkatkan Motivasi Belajar pada Mata Kuliah Keperawatan Dasar : Nutrisi di STIKes Karsa Husada Garut

Tabel 4.5

Uji Normalitas Data

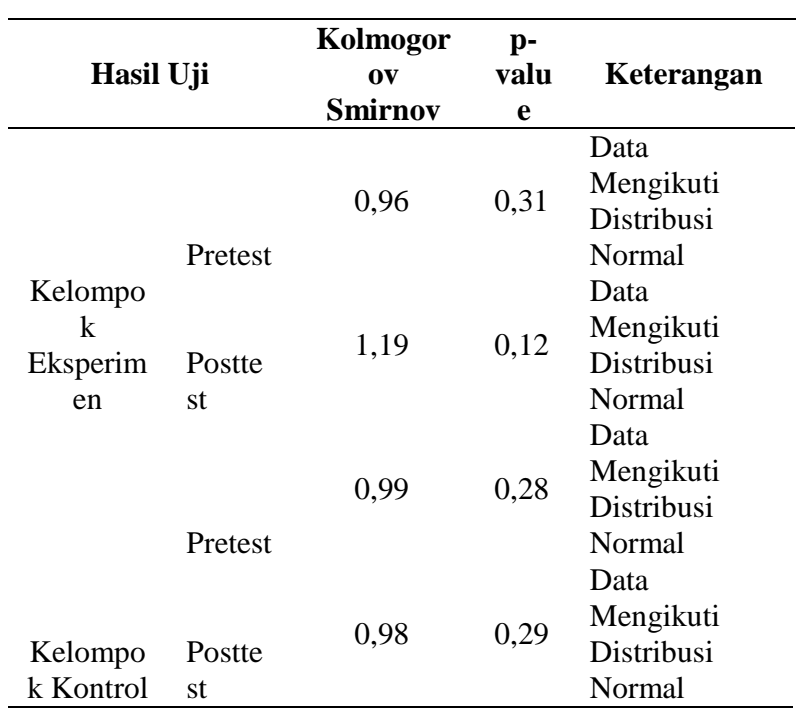

Tabel 4.6

Hasil Uji Homogenitas

\begin{tabular}{|c|c|c|c|c|}
\hline \multicolumn{2}{|c|}{ Hasil Uji } & $\begin{array}{c}\text { Levene } \\
\text { Test }\end{array}$ & $\begin{array}{c}\text { p- } \\
\text { value }\end{array}$ & Keterangan \\
\hline & Pretest & 0,23 & 0,64 & Data Homogen \\
\hline Motivasi & Posttest & 10,99 & 0,00 & $\begin{array}{l}\text { Data Tidak } \\
\text { Homogen }\end{array}$ \\
\hline
\end{tabular}

Tabel 4.7

Hasil Uji t Dependen Motivasi belajar pada kelompok Ekperimen Dan Kelompok Kontrol

\begin{tabular}{lcccc}
\hline \multirow{2}{*}{ Kelompok } & \multicolumn{2}{c}{ Rata-rata Hasil Belajar } & \multirow{2}{t}{} & $\begin{array}{c}\mathrm{p}- \\
\text { value }\end{array}$ \\
\cline { 2 - 3 } hretest & Posttest & hitung & val \\
\hline Eksperimen & 121,13 & 131,16 & $-6,04$ & 0,00 \\
Kontrol & 119,20 & 124,33 & $-5,52$ & 0,00 \\
\hline
\end{tabular}




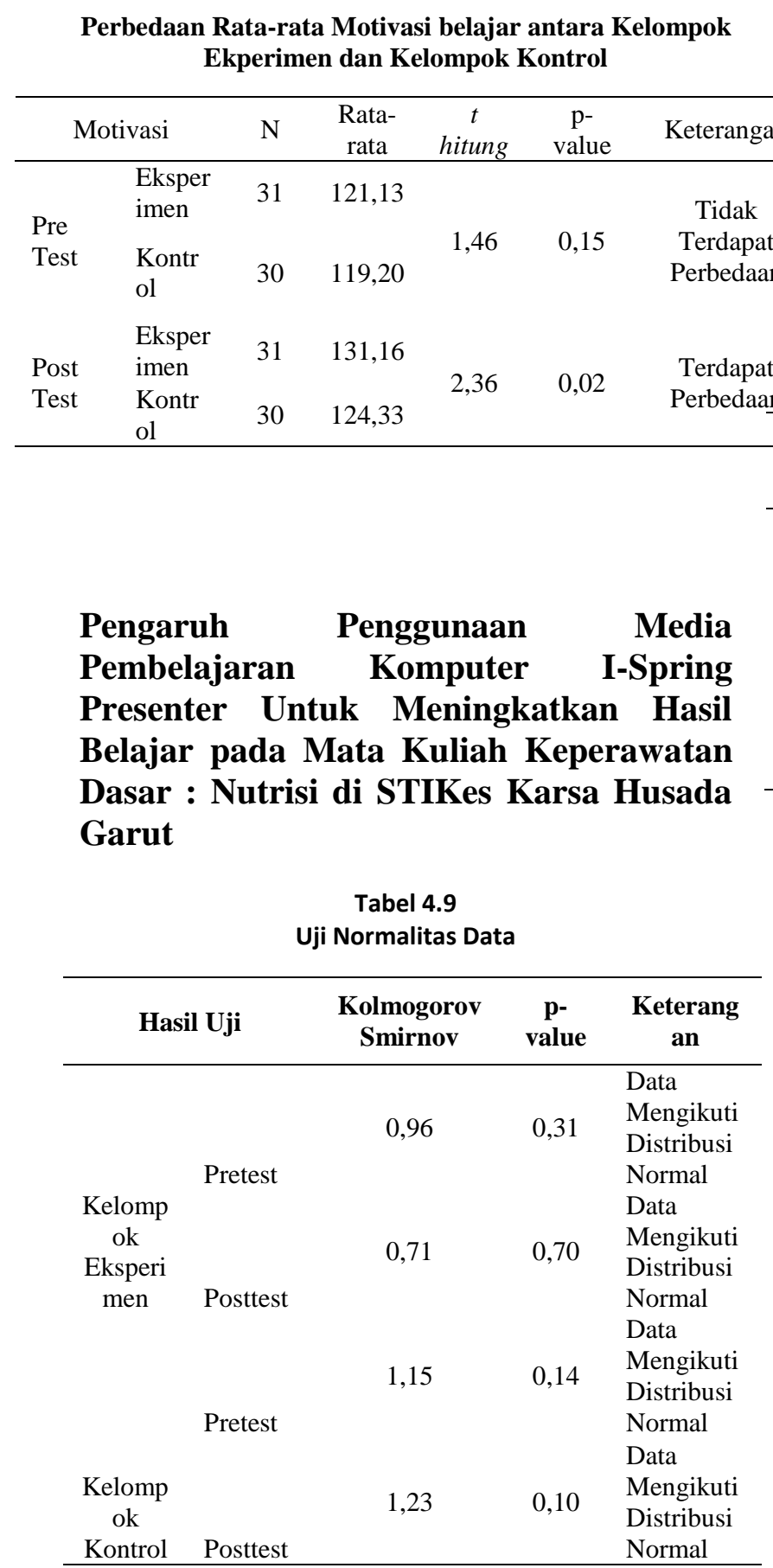

Tabel 4.10

Hasil Uji Homogenitas

\begin{tabular}{|c|c|c|c|c|}
\hline \multicolumn{2}{|c|}{ Hasil Uji } & \multirow{2}{*}{$\begin{array}{c}\text { Levene } \\
\text { Test } \\
0,71\end{array}$} & \multirow{2}{*}{$\begin{array}{c}\begin{array}{c}\text { p- } \\
\text { value }\end{array} \\
0,44\end{array}$} & \multirow{2}{*}{$\begin{array}{l}\text { Keterangan } \\
\text { Data } \\
\text { Homogen }\end{array}$} \\
\hline & Pretest & & & \\
\hline $\begin{array}{l}\text { Hasil } \\
\text { belajar }\end{array}$ & Posttest & 1,58 & 0,21 & $\begin{array}{l}\text { Data } \\
\text { Homogen }\end{array}$ \\
\hline
\end{tabular}

Tabel 4.11

Hasil Uji t Dependen Hasil Belajar pada kelompok Ekperimen Dan Kelompok Kontrol

Tabel 4.12

Perbedaan Rata-rata Hasil Belajar antara Kelompok Ekperimen dan Kelompok Kontrol

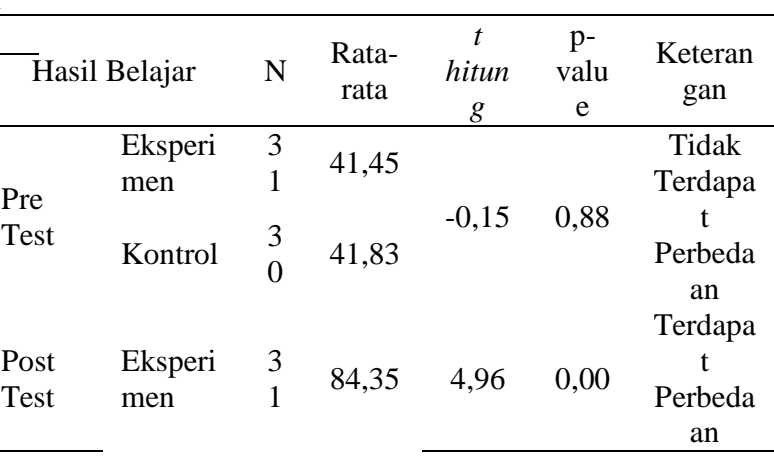

$\begin{array}{lrr}\text { Gambaran } & \text { Penggunaan } & \text { Media } \\ \text { Pembelajaran } & \text { Komputer } & \text { I-Spring }\end{array}$
Presenter Terhadap Motivasi dan Hasil Belajar pada Mata Kuliah Keperawatan Dasar : Nutrisi di STIKes Karsa Husada Garut

Hasil dari analisis menyatakan bahwa penggunaan media pembelajaran komputer $i$-spring presenter dapat meningkatkan motivasi maupun hasil belajar, peningkatan yang didapatkan pada motivasi dan hasil belajar sangat signifikan.

Deskripsi tabel motivasi belajar mahasiswa Program Profesi Ners STIKes Karsa Husada Garut sudah memiliki motivasi belajar yang baik walaupun belum diberikan perlakuan penggunaan media pembelajaran $i$-spring presenter. Setelah diberikan perlakuan pengajaran dengan menggunakan media pembelajaran i-spring presenter terdapat peningkatan 10,03 point, sedangkan perlakuan pengajaran dengan menggunakan metode konvensional atau tanpa menggunakan media pembelajaran hanya mendapatkan peningkatan 5,13 point. 
Untuk Deskripsi tabel hasil belajar mahasiswa Program Profesi Ners STIKes Karsa Husada Garut didapatkan mahasiswa yang belum diberikan perlakuan pengajaran dengan media pembelajaran komputer $i$ spring presenter dan perlakuan pengajaran dengan metode konvensional atau tanpa menggunakan media pembelajaran mempunyai nilai hasil evaluasi belajar yang rendah. Setelah dilakukan perlakuan pengajaran dengan menggunakan media pembelajaran komputer $i$-spring presenter mahasiswa Program Profesi Ners STIKes Karsa Husada Garut memperoleh hasil yang sangat siginifikan. Peningkatan nilai hasil belajar 42,9 point lebih tinggi dibandingkan dengan mahasiswa yang menggunakan metode konvensional atau tanpa menggunakan media hanya memperoleh peningkatan hasil belajar 31, 17 point. Signifikansi peningkatan yang didapatkan oleh mahasiswa Program Profesi Ners STIKes Karsa Husada Garut yang memperoleh pengajaran dengan menggunakan media pembelajaran $i$-spring presenter dari kategori nilai belajar kurang menjadi tinggi. Berbeda dengan pengajaran menggunakan metode konvensiobal atau tanpa menggunakan media pembelajaran dari kategori nilai kurang menjadi kategori cukup.

\section{Pengaruh \\ Penggunaan \\ Pembelajaran Komputer \\ Media \\ Belajar pada Mata Kuliah Keperawatan Dasar : Nutrisi di STIKes Karsa Husada Garut}

Berdasarkan data hasil diatas terdapat pengaruh yang signifikan penggunaan media pembelajaran i-spring presenter terhadap motivasi belajar antara kelas eksperimen dan kelas kontrol yang signifikan. Kelas eksperimen walaupun nilai pretest lebih kecil dibandingkan kelas kontrol peningkatan hasil posttestnya jauh lebih signifikan dan lebih. Sehingga dapat disimpulkan bahwa capaian peningkatan menggunakan media pembelajaran komputer i-spring lebih berpengaruh dibandingkan dengan tanpa menggunakan media pembelajaran komputer i-spring presenter.

\section{Pengaruh Penggunaan Media Pembelajaran Komputer I-Spring Presenter Untuk Meningkatkan Hasil Belajar pada Mata Kuliah Keperawatan Dasar : Nutrisi di STIKes Karsa Husada Garut}

Pembelajaran sebelum menggunakan media pembelajaran komputer i-spring presenter lebih menekankan pada aspek psikomotor sehingga pemahaman mahasiswa dalam praktik keperawatan dasar : nutrisi secara tindakan keperawatannya hanya mampu melaksanakan praktikum saja tanpa mengetahui pemahaman materi tersebut secara keseluruhan sehingga mahasiswa hanya berfokus kepada kelulusan praktikum saja.

Berbeda dengan hal tersebut, penggunaan media pembelajaran komputer i-spring presenter ternyata mampu meningkatkan kapasitas pemahaman kognitif mahasiswa sehingga pelaksanaan praktikum dapat disempurnakan dengan adanya peningkatan pemahaman tersebut.

\section{E. SIMPULAN DAN REKOMENDASI}

Berdasarkan hasil penelitian dan pembahasan pada bab sebelumnya maka dapat disimpulkan antara lain:

1. Penggunaan media pembelajaran komputer $i$-spring presenter dapat meningkatkan motivasi dan hasil belajar secara signifikan dibandingkan dengan metode konvensional atau tanpa menggunakan media pembelajaran walaupun hasil sebelumnya mahasiswa program profesi ners STIKes Karsa Husada Garut mempunyai skor motivasi dan nilai hasil belajar rendah atau kurang.

2. Penggunaan media pembelajaran komputer $i$-spring presenter berpengaruh positif atau dapat 
meningkatkan motivasi belajar mahasiswa program profesi ners STIKes Karsa Husada Garut.

3. Penggunaan media pembelajaran komputer $i$-spring presenter berpengaruh positif atau dapat meningkatkan hasil belajar mahasiswa program profesi ners STIKes Karsa Husada Garut.

Penggunaan media pembelajaran komputer i-spring diharapkan dapat digunakan oleh dosen untuk mengembangkan keterampilan mahasiwa dalam aspek kognitif dan aspek afektif sehingga dapat mempermudah dalam memberikan pembelajaran kepada mahasiswa maupun peserta didik dalam mengembangkan sesuai dengan mekanisme gaya belajar.

Sebagai program pengembangan dan peningkatan kepada dosen pengajar untuk memahami dan menggunakan media pembelajaran yang interaktif khususnya program aplikasi komputer, e-learning, dan website learning untuk diterapakan dalam aplikasi pengajaran kepada mahasiswa.

\section{F. REFERENSI}

Anitah, S. (2009). Teknologi Pembelajaran . Surakarta : Yuma Pustaka.

Arsyad, M. (2011). Media Pembelajaran. (Edisi I). Jakarta: Rineka Cipta. (2012). Media Pembelajaran. (Edisi II). Jakarta: Rineka Cipta

Hamalik, U.,(2005). Dasar-dasar Pembelajaran. Bandung: Madar Maju.

Djamarah. (2002). Teori Motivasi, edisi 2 (ed-2), Jakarta : PT. Bumi Aksara

Nana Sudjana dan Ahmad Rivai. (2001). Media Pengajaran. Bandung: Sinar Baru.

Rahmadi Suka, (2009). Pengaruh Pemanfaatan Media Pembelajaran OHP dan Komputer Menggunakan
Program Power Point terhadap

Prestasi Belajar IPS ditinjau dari Belajar Siswa Kelas XII Sekolah Menengah Atas Negeri di Kecamatan Wonosari Kabupaten Gunung Kidul, Gunung Kidul : Tidak Diterbitkan.

Sadiman.A. (2011). Belajar dan Pembelajaran: Yokayakarta: Pustaka Pelajar.

STIKES. (2014). Ilmu Keperawatan Dasar . Garut: Modul Pembelajaran Dosen Stikes. Karsa Husada. (Tidak DIterbitkan).

Suunk. (2012). Definition of Motivation. New York: Prentice-Hall Company. 